Gut, 1973, 14, 545-548

\title{
Studies of carcinoembryonic antigen activity of whole and extracted serum in ulcerative colitis
}

\author{
S. K. KHOO, P. S. HUNT, AND I. R. MACKAY
}

From the Clinical Research Unit of The Walter and Eliza Hall Institute of Medical Research and The Royal Melbourne Hospital, Victoria, and Monash University Department of Surgery, Prince Henry's Hospital, Melbourne, Victoria, Australia

SUMMARY The present study has used a microradioimmunoassay to detect carcinoembryonic antigen(s) (CEA) in whole and extracted serum in 77 patients with ulcerative colitis, two of whom had coexisting colonic carcinoma, and 69 patients with carcinoma of the colon or rectum. Taking $5 \mathrm{ng} / \mathrm{ml}$ as the level of positivity, the CEA assay on whole serum showed positive results in patients with 'active' ulcerative colitis (15 of 17) but not in those with 'inactive' disease ( 0 of 23$)$. In two patients, levels fell during drug-induced remission. Our results also indicated that a positive result for CEA on extracted serum was associated with carcinomatous changes in ulcerative colitis in contrast to uncomplicated ulcerative colitis in which positive results were obtained only with whole serum.

There is an interesting discrepancy in results in studies on serum levels of carcinoembryonic antigen (CEA) in ulcerative colitis. Using plasma which received prior treatment with perchloric acid, Lo Gerfo, Krupey, and Hansen (1971) and Rule, Straus, Vandevoorde, and Janowitz (1972) found CEA in $30 \%$ of patients with ulcerative colitis whereas, using serum similarly treated, Zamcheck, Moore, Dhar, and Kupchik (1972) failed to detect CEA in patients with uncomplicated ulcerative colitis, and Moore, Kantrowitz, and Zamcheck (1972) found only transient positivity in six of 60 cases. Differences in case selection and varying degrees of disease activity or in methodology have been considered as factors to explain this difference. We have tested for CEA in whole and extracted serum, in patients with ulcerative colitis, using a microradioimmunoassay. In 'active' ulcerative colitis, CEA-like activity was detectable only in whole serum and not in serum first treated with perchloric acid as in conventional procedures, whereas in carcinoma of the colon or rectum CEA-like activity was demonstrable before and after treatment of serum with perchloric acid.

\section{Materials and Methods}

\section{PATIENTS}

The study group comprised 77 patients with Received for publication 12 April 1973. ulcerative colitis, in two of whom carcinoma of the colon had supervened, and 69 with carcinoma of the colon or rectum, this diagnosis being established at operation and confirmed histologically.

There were 40 patients with ulcerative colitis who had not undergone colectomy, and 35 patients who had had colectomy and ileo-rectal anastomosis. At the time of testing for CEA, colitis was graded as 'active' or 'inactive'; the criteria for 'activity' were diarrhoea containing blood and mucus, sigmoidoscopic appearances of redness, oedema, and contact bleeding, and biopsy evidence of mucosal inflammation. There were two patients with ulcerative colitis and coexisting colonic carcinoma, in one of whom sera were available long before the diagnosis of carcinoma was made.

MICRORADIOIMMUNOASSAY OF CEA IN SERUM This was performed on $0.025 \mathrm{ml}$ of whole serum or serum extracted with perchloric acid as described by MacSween, Warner, Bankhurst, and Mackay (1972) and MacSween, Warner, and Mackay (1973); the assay is based on the capacity of CEA or CEA-like substances to inhibit the reaction between radiolabelled ${ }^{125}$ I CEA and specific antiserum to CEA. In the present study, this inhibitory activity is referred to as 'CEA activity', recognizing that it may represent reactive substances with different physicochemical properties. Under the conditions of the assay, the lower limit at which CEA activity could 


\begin{tabular}{|c|c|c|c|c|c|}
\hline \multirow[t]{2}{*}{ Diagnosis } & \multirow[t]{2}{*}{ No. of Patients } & \multicolumn{3}{|c|}{ CEA in Serum $(n g / m l)$} & \multirow{2}{*}{$\begin{array}{l}\text { Percentage } \\
\text { Positive Results } \\
(>5 \mathrm{ng} / \mathrm{ml})\end{array}$} \\
\hline & & $5-10$ & $11-20$ & $>20$ & \\
\hline $\begin{array}{l}\text { 'Active' colitis } \\
\text { 'Inactive' colitis } \\
\text { Total colectomy and ileo-rectal anastomosis } \\
\text { Coexisting carcinoma and ulcerative colitis } \\
\text { Carcinoma of colon or rectum }\end{array}$ & $\begin{array}{r}17 \\
23 \\
35 \\
2 \\
69\end{array}$ & $\begin{array}{r}6 \\
0 \\
2 \\
0 \\
14\end{array}$ & $\begin{array}{r}4 \\
0 \\
1 \\
2 \\
19\end{array}$ & $\begin{array}{r}5 \\
0 \\
1 \\
0 \\
33\end{array}$ & $\begin{array}{r}88 \\
0 \\
11\end{array}$ \\
\hline
\end{tabular}

Table I Carcinoembryonic antigen in whole serum in ulcerative colitis and carcinoma of colon or rectum

be detected was $3 \mathrm{ng} / \mathrm{ml}$, and the level for positivity was arbitrarily taken as $5 \mathrm{ng} / \mathrm{ml}$.

\section{Results}

The incidence of levels of CEA activity greater than $5 \mathrm{ng} / \mathrm{ml}$ in whole serum in ulcerative colitis and in carcinoma of the colon or rectum is shown in table $I$. Carcinoembryonic antigen activity in whole serum was detected in 15 of 17 patients with 'active' ulcerative colitis, but in none of 28 patients with 'inactive' ulcerative colitis; in $30 \%$ of the patients with 'active' colitis, the CEA activity exceeded $20 \mathrm{ng} / \mathrm{ml}$. After colectomy only four of 35 patients gave a positive result and, in these four patients, there was proctoscopic evidence of active disease in the rectal stump. Of 69 patients with carcinoma of the colon or rectum, $95 \%$ had levels of CEA activity in whole serum exceeding $5 \mathrm{ng} / \mathrm{ml}$ and $50 \%$ had levels exceeding $20 \mathrm{ng} / \mathrm{ml}$.

The effect of extraction with perchloric acid was examined in sera which showed positive results for CEA; sera were tested from 17 patients with ulcerative colitis and 22 with carcinoma of the colon or rectum (table II). In ulcerative colitis, CEA activity became undetectable after extraction, despite initial levels in 10 patients greater than $10 \mathrm{ng} / \mathrm{ml}$, whereas CEA activity remained detectable after extraction in 21 of 22 patients with carcinoma, the one exception having a level in whole serum of only $6 \mathrm{ng} / \mathrm{ml}$. In the two patients with ulcerative colitis and coexisting carcinoma, CEA activity was detectable in serum before and after extraction; in one, stored sera obtained up to three years before the clinical diagnosis of carcinoma showed elevated levels of activity in whole serum and in serum after extraction (see fig).

In two patients with active ulcerative colitis, sequential estimations of CEA in unextracted serum showed that levels fell from 10 and $15 \mathrm{ng} / \mathrm{ml}$ to zero

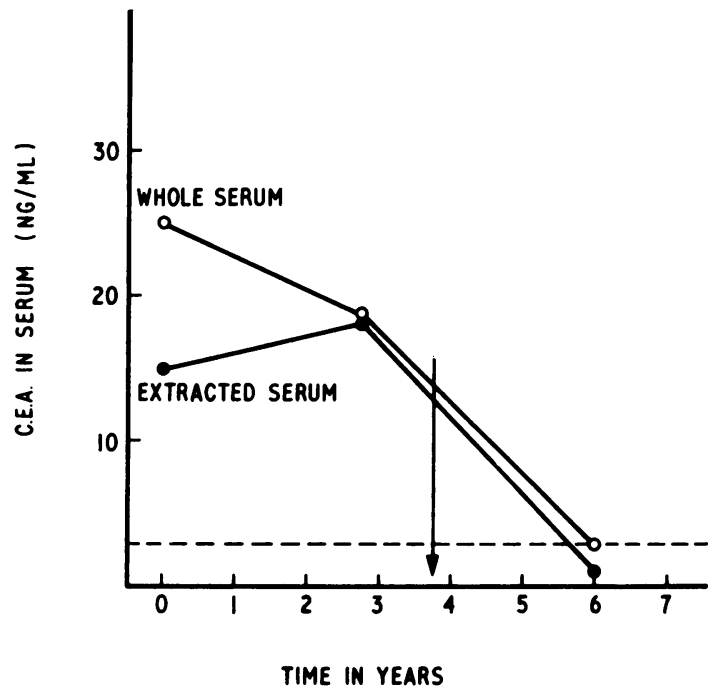

Fig Levels of CEA in whole serum and serum extracted with perchloric acid from a patient with ulcerative colitis in whom stored serum samples were available. Results were positive three years before colonic carcinoma was diagnosed (arrow); postcolectomy samples were negative.

\begin{tabular}{|c|c|c|c|c|c|c|c|}
\hline \multirow[t]{2}{*}{ Diagnosis } & \multirow[t]{2}{*}{ No. of Patients } & \multirow{2}{*}{$\begin{array}{l}\text { Treatment of } \\
\text { Serum with } \\
\text { Perchloric Acid } \\
(\text { PCA })\end{array}$} & \multicolumn{4}{|c|}{ CEA in Serum $(n g / m l)$} & \multirow{2}{*}{$\begin{array}{l}\text { Percentage } \\
\text { Positive Results } \\
\text { after PCA } \\
\text { Treatment }\end{array}$} \\
\hline & & & $<5$ & $5-10$ & $11-20$ & $>20$ & \\
\hline Ulcerative colitis & 17 & $\begin{array}{l}\text { Whole serum } \\
\text { Extracted }\end{array}$ & $\begin{array}{r}0 \\
17\end{array}$ & $\begin{array}{l}7 \\
0\end{array}$ & $\begin{array}{l}4 \\
0\end{array}$ & $\begin{array}{l}6 \\
0\end{array}$ & $\mathbf{0}$ \\
\hline Coexisting carcinoma and ulcerative colitis & 2 & $\begin{array}{l}\text { Whole serum } \\
\text { Extracted }\end{array}$ & $\begin{array}{l}\mathbf{0} \\
\mathbf{0}\end{array}$ & $\begin{array}{l}\mathbf{0} \\
1\end{array}$ & $\begin{array}{l}2 \\
1\end{array}$ & $\begin{array}{l}\mathbf{0} \\
\mathbf{0}\end{array}$ & \\
\hline
\end{tabular}


during remission induced by prednisolone and azathioprine.

\section{Discussion}

The detection of CEA in serum by radioimmunoassay is a new procedure for the diagnosis of carcinoma of the colon (Zamcheck et al, 1972), but the specificity of the assay for cancer is being questioned. Carcinoembryonic antigen-like activity in tissue extracts has been demonstrated in non-malignant inflammatory conditions of the colon (Martin and Martin, 1972) and normal adult colon (Lo Gerfo, Lo Gerfo, Herter, Barker, and Hansen, 1972), as well as in faeces of apparently healthy individuals (Freed and Taylor, 1972). Thus the different assayable levels of CEA in carcinoma and certain nonmalignant diseases may well be quantitative, and not attributable to the appearance in malignant disease of a cancer-specific antigen. The substances giving CEA activity in serum in various nonmalignant diseases are so far not characterized, and may represent different types of molecule with crossreactive sites. Presumably, the reactive substances detected in tests for CEA on whole serum in our assay system represent molecules containing different carbohydrate moieties with differing solubility after treatment with perchloric acid. If so, one molecular component present in association with 'active' ulcerative colitis would be precipitated or modified by treatment of serum with perchloric acid, whereas another component present in association with carcinoma of the colon would remain in solution after treatment with perchloric acid. Our findings of absent CEA activity in serum extracted with perchloric acid, in ulcerative colitis, are in line with those of Zamcheck et al (1972).

Positive tests for CEA were obtained in 10 of 31 patients with uncomplicated ulcerative colitis by Lo Gerfo et al (1971), using an assay dependent on an ion-sensitive site, whereas negative tests were reported for 75 cases by Zamcheck et al (1972) who used the radioimmunoassay described by Thomson, Krupey, Freedman, and Gold (1969). The level of CEA required for positivity in the different immunoassays for CEA is still arbitrary and this would be a contributory factor to the different results reported in ulcerative colitis. For example, a level of $1.1 \mathrm{ng}$ of CEA per $\mathrm{ml}$ has been demonstrated in pooled human serum after extraction (Chu, Reynoso, and Hansen, 1972); hence, when a critical level for positivity was accepted as $1 \mathrm{ng} / \mathrm{ml}$, as was done in one study with a considerably modified assay by LeBel, Deodhar, and Brown (1972), positive results were obtained in most patients with ulcerative colitis $(75 \%)$ and diverticulitis $(66 \%)$. Considering a lower limit of
$2.5 \mathrm{ng} / \mathrm{ml}$ of CEA in plasma, $27 \%$ of patients with ulcerative colitis and $37 \%$ with Crohn's disease gave positive results (Rule et al, 1972), but here there was no discrimination between 'active' and 'inactive' phases. Thus the differing results for CEA positivity in ulcerative colitis could be due to differences in assay techniques and reagents, the critical level accepted for a positive result, and case selection.

Using a microradioimmunoassay on whole serum, we have taken a critical level of positivity of 5 $\mathrm{ng} / \mathrm{ml}$, basing this on our experience with a population of 230 'controls' of whom only $3 \%$ showed levels exceeding this (Khoo and Mackay, 1973). This level appeared to differentiate patients with 'active' and 'inactive' ulcerative colitis. Limited data from sequential testing, from this study and that of Moore et al (1972), indicate that CEA levels, particularly using whole serum, could prove useful in assessing the degree of remission of ulcerative colitis induced by antiinflammatory and immunosuppressive drugs.

We note that carcinoma of the colon behaves differently when it supervenes on ulcerative colitis; it is more undifferentiated (Hinton, 1966), appears in multiple sites in up to $42 \%$ of patients (Kronman, 1971), occurs at an earlier age of life (Brooke, 1969), and is located more often in clinically 'silent' areas in the ascending and transverse colon (Counsell and Dukes, 1952). Furthermore the risk of carcinoma is markedly increased in ulcerative colitis (Burdette, 1971), and its prognosis is poor with a five-year survival rate of 19 to $32 \%$ (Brooke, 1969). Our preliminary finding of positive results with whole serum, and serum after extraction, only in patients with colonic carcinoma complicating ulcerative colitis, supports the CEA assay as a useful means of detecting these carcinomatous changes in ulcerative colitis.

We thank Dr N. L. Warner for his interest in the work and for providing us with ${ }^{125}$ I CEA for the assay, and Dr R. G. Strickland for his assistance with some of the patients. The work was supported by grants from the National Health and Medical Research Council of Australia and the Queensland Cancer Fund.

\section{References}

Brooke, B. N. (1969). Ulcerative colitis and carcinoma of the colon. J. roy. Coll. Surg. Edinb., 14, 274-278.

Burdette, W. J. (1971). Identification of antecedents to colorectal cancer. Cancer (Philad.), 28, 52-59.

Chu, T. M., Reynoso, G., and Hansen, H. J. (1972). Demonstration of carcinoembryonic antigen in normal human plasma. Nature (Lond.), 238, 152-153.

Counsell, P. B., and Dukes, C. E. (1952). The association of chronic ulcerative colitis and carcinoma of the rectum and colon. Brit. J. Surg., 39, 485-495. 
Freed, D. L. J., and Taylor, G. (1972). Carcinoembryonic antigen in faeces. Brit. med.J., 1, 85-87.

Hinton, J. M. (1966). Risk of malignant change in ulcerative colitis. Gut, 7, 427-432.

Khoo, S. K., and Mackay, I. R. (1973). Carcinoembryonic antigen in serum in diseases of the liver and pancreas. J. clin. Path. in press.

Kronman, B. S. (1971). Ulcerative colitis, autoimmune epiphenomena, and colonic cancer. Cancer (Philad.), 28, 82-88.

LeBel, J. S., Deodhar, S. D., and Brown, C. H. (1972). Evaluation of a radioimmunoassay for carcinoembryonic antigen of the human digestive system. Cleveland Clin. Quart., 39, 25-31.

Lo Gerfo, P., Krupey, J., and Hansen, H. J. (1971). Demonstration of an antigen common to several varieties of neoplasia. New Engl. J. Med., 285, 138-141.

Lo Gerfo, P., Lo Gerfo, F., Herter, F., Barker, H. G., and Hansen, H. J. (1972). Tumor-associated antigen in patients with carcinoma of the colon. Amer. J. Surg., 123, 127-131.

MacSween, J. M., Warner, N. L., Bankhurst, A. D., and Mackay, I. R. (1972). Carcinoembryonic antigen in whole serum. Brit. J. Cancer, 26, 356-360.
MacSween, J. M., Warner, N. L., and Mackay, I. R. (1973). The detection of carcinoembryonic antigen in whole serum from patients with malignant and non-malignant disease. Clin. Immunol. Immunopath., 1, 330.

Martin, F., and Martin, M. S. (1972). Radioimmunoassay of carcinoembryonic antigen in extracts of human colon and stomach. Int. J. Cancer, 9, 641-647.

Moore, T. L., Kantrowitz, P. A., and Zamcheck, N. (1972). Carcinoembryonic antigen (CEA) in inflammatory bowel disease. $J$. Amer. med. Ass., 222, 944-947.

Rule, A. H., Straus, E., Vandevoorde, J., and Janowitz, H. D. (1972). Tumor-associated (CEA-reacting) antigen in patients with inflammatory bowel disease. New Engl. J. Med., 287, 24-26.

Thomson, D. M. P., Krupey, J., Freedman, S. O., and Gold, P. (1969). The radioimmunoassay of circulating carcinoembryonic antigen of the human digestive system. Proc. nat. Acad. Sci. (Wash.), 64, 161-167.

Zamcheck, N., Moore, T. L., Dhar, P., and Kupchik, H. (1972). Immunological diagnosis and prognosis of human digestive, tract cancer: carcinoembryonic antigens. New Engl. J. Med., 286, 83-86. 